\title{
Contents, Vol. 17, 1985
}

\section{No. 1 Original Paper}

Studies on Cataractogenesis in Humans and in Rats with Alloxan-Induced Diabetes.

I. Cation Transport and Sodium-Potassium-Dependent ATPase

Ahmad, S.S.; Tsou, K.C.; Ahmad, S.I.; Ataur Rahman, M.; Kirmani, T.H 1

Studies on Cataractogenesis in Humans and in Rats with Alloxan-Induced Diabetes.

II. Histochemical Evaluation of Lenticular Enzymes

Ahmad, S.S.; Tsou, K.C.; Ahmad, S.I.; Ataur Rahman, M 12

In vivo Color Analysis of Human Crystalline Lenses

Sasaki, K.; Hiiragi, M.; Sakamoto, Y.; Shibata, T 21

Disparate Effects of Calmodulin Inhibitors on Corneal Epithelial Migration in Rabbit and

Rat

Kaz Soong, H.; Cintron, C. . 27

Colloidal Carbon as a Combined Ophthalmoscopic, and Microscopic Probe of Retinal and

Choroidal Vascular Integrity (With 1 color plate)

Cerro, M. del; Grover, D.A.; Dematte, J.E.; Williams, W.M.; Ishida, N 34

Changes of Some Biochemical Parameters of the Lens in Galactose-Treated Weaned Rats

with and without Vitamin E Therapy

Libondi, T.; Menzione, M.; Iuliano, G.; Delia Corte, M.; Latte, F.; Auricchio, G. . . 42 Are B-

Adrenergic Mechanisms Involved in Ocular Hypotensive Actions of Adrenergic

Drugs?

Chiou, G.C.Y.; Watanabe, K.; McLaughlin, M.A.; Liu, H.K 49

Intraocular Lenses, Tilt and Astigmatism

Sivak, J.G.; Kreuzer, R.O.; Hildebrand, T 54

Morphological Study on the Human Developing Vitreous Collagen Fibrils and Persistent

Hyperplastic Primary Vitreous

Akiya, S.; Uemura, Y.; Azuma, N 60

No. 2 Original Paper

Quantitative Assessment of Ocular Norepinephrine Concentration in the Rabbit Using

Liquid Chromatography with Electrochemical Detection

Gherezghiher, T.; Koss, M.C 65

Effect of Pilocarpine in Ocular Hypotension

Korczyn, A.D.; Carel, R.S.; Goya, V 72

Posterior Capsule Opacification: Experimental Analyses

Odrich, M.G.; Hall, S.J.; Worgul, B.V.; Trokel, S.L.; Rini, F.J 75

The Inhibition of Bovine Lens Aldose Reductase by Clinoril, Its Absoption into the Human Red Cell and Its Effect on Human Red Cell Aldose Reductase Activity

Crabbe, M.J.C.; Freeman, G.; Haider, A.B.; Bron, A.J 85

IV

Contents 
In vivo Assessment of Lens Transmission for Blue-Green Light by Autofluorescence Measurement

Best, J.A. van; Tsoi, T.A.E.W.S.J.; Boot, J.P.; Oosterhuis, J.A 90

Monitoring Lens Transparency during in vitro Incubation by Scheimpflug Photography and Densitometric Image Analysis

Hockwin, O.; Dragomirescu, V.; Schwarz, B 96

Change in Vitreous Collagen after Penetrating Injury

Raymond, L.A.; Choromokos, E.; Bibler, L.W.; Spaulding, A.G.; Alexander, D.W.;

Kao, W.W.-Y 102

New Approach to Area Image Analysis of Scheimpflug Photos of the Anterior Eye

Segment

Mayer, H.; Irion, K.M106

Innervation of the Human Pupillary Sphincter Muscle by Nerve Fibers Immunoreactive to

Substance P

Tervo, T.; Tarkkanen, A.; Tervo, K 111

Comparison of Aldose Reductase Inhibitors by Determination of IC50 with Bovine and Rat

Lens Extracts

Müller, P.; Hockwin, O.; Ohrloff, C 115

Pharmacological Study on the Effects of Some Ocular Hypotensive Drugs on Aqueous

Humor Formation in the Arterially Perfused Enucleated Rabbit Eye

Kodama, T.; Reddy, V.N.; Macri, F.J120

No. 3 Original Paper

Light and Electron Microscopic Studies of the Rat Hyalocyte after Perfusion Fixation

Salu, P.; Claeskens, W.; De Wilde, A.; Hijmans, W.; Wisse, E 125

Treatment of Blood Hyperviscosity with Calcium Dobesilate in Patients with Diabetic Retinopathy

Benarroch, I.S.; Brodsky, M.; Rubinstein, A.; Viggiano, C; Salama, E.A 131

Induction and Down-Regulation of Conjunctival Type-I Hypersensitivity Reactions in

Guinea Pigs Sensitized Topically with Fluoresceinyl Ovalbumin

Khatami, M.; Donnelly, J.J.; Rockey, J.H 139

Exocytosis by Retinal Pigment Epithelial Cells

Matsumura, M.; Ogino, N.; Shirakawa, H.; Yamakawa, R.; Tsukahara, 1148

Fluctuations of Light Absoption of Healthy Papillae Repeatedly Photographed Over a Long

Period of Time

Robert, Y.; Gschwind, R.; Bruckner, R 154

Identification of Type II Procollagen in Rabbit Vitreous

Hong, B.-S.; Davison, P.F 162

Direct in vivo Measurement ofCorneal Epithelial Metabolic Activity Using a Polarographic Oxygen Sensor

Holden, B.A.; Sulonen, J.; Vannas, A.; Sweeney, D.F.; Efron, N 168

Anti-Myelin Basic Protein Antibody in Experimental Allergic Optic Neuritis and Encephalomyelitis

Robin, J.B.; Phillips, T.M.; Rao, N.A 174

Lactate Transport through the Blood-Retinal and the Blood-Brain Barrier in Rats

Aim, A.; Törnquist, P 181

Chemical Modification Studies on Purified Bovine Lens Aldose Reductase 
Haider, A.B.; James, M.; Crabbe, C 185

Contents

$\mathrm{V}$

No. 4 Abstracts

25th Meeting of the Association for Eye Research, Lund, Sweden, August 28-32, 1984 . 189

Original Paper

Intercellular Junctions in the Developing Rat Corneal Endothelium

Montcourrier, P.; Hirsch, M 207

Translation of Type IV Procollagen Messenger RNA from Cultured Cat Retinal Pigment Epithelial Cells

Shen, S.; Stramm, L.E.; Li, W.; Robertson, G.A.; Aguirre, G.D.; Rockey, J.H 216

Fine Structure of the Retinal Pigment Epithelial Region of the Archerfish (Toxotes

jaculatrix)

Braekevelt, C.R 221

Effect of Ocular Blood Flow Changes on the Efferent Activity of Cat Ciliary Nerves

Gual, A.; Castro, F.R. de 230

Vasoactive Intestinal Polypeptide(VIP)-Immunoreactive Nerve Fibers in the Anterior Uvea

of the Guinea Pig

Uusitalo, H.; Lehtosalo, J.I.; Palkama, A 235

Binocular Disparity in Visual Evoked Responses. Clinical Evidence in Normal and Stereo-blind

Subjects

Nuzzi, G.; Franchi, A 241

Low Temperature and Acrylamide Inhibit Lens Opacification Caused by Calcium

Clark, J.I.; Danford, M.E 246

Continuous Usage of Low Doses of Human Leukocyte Interferon with Contact Lenses in

Herpetic Keratoconjunctivitis

Reccia, R.; Prete, A. del; Benusiglio, E.; Orfeo, V $2 \$ 1$

No. 5 Original Paper

Electron Microscopic Study of Water-Insoluble Fractions in Normal and Cataractous

Human Lens Fibers

Ozaki, L.; Jap, P.; Bloemendal, H 257

Ornithine Decarboxylase in Developing Neonatal Rabbit Ocular Tissue

Foresman, G.E.; Cohen, R.J.; Das, N.D 262

Phosphorus-31 NMR Analysis of Dynamic Energy Metabolism in Intact Crystalline Lens

Treated with Ouabain: Phosphorylated Metabolites

Greiner, J.V.; Kopp, S.J.; Glonek, T. . 269

Treatment of Vitreous Hemorrhage in Rh-Positive Patients by Intravitreal Injection of Anti-

Rh0-Immunoglobulin

Morawiecki, J.; Geursen, R.G2TM

Identification and Partia Purification of a Nucleotide-Stimulated Protease in Rat Retina

Tsung, P.-K.; Lombardini, J.B 282

Pseudomonas aeruginosa Induced Infection. A Histological Comparison of Two Bacterial

Strains of Different Virulence

Hazlett, L.D.; Zelt, R.; Cramer, C; Berk, R.S289

Antioxidant Modulation of Phacoanaphylactic Endophthalmitis

Marak, G.E., Jr.; Rao, N.A.; Scott, J.M.; Duque, R.; Ward, P.A 
Biochemical Model Reactions for Cataract Research

Elstner, E.F.; Adamczyk, R.; Furch, A.; Kroner, R 302

VI

Contents

Oculo-Oscillo-Dynamography: A Diagnostic Procedure for Recording Ocular Pulses and Measuring Retinal and Ciliary Arterial Blood Pressures

Ulrich, W.-D.; Ulrich, C 308

Comparison of Leukotrienes as Conjunctival Microvascular Permeability Factors

Woodward, D.F.; Ledgard, S.E 318

No. 6 Original Paper

Content and Distribution of Calcium in Bovine Lenses of Different Ages

Rink, H.; Twenhöven, H 321

The Association between Pinguecula, Sunlight and Cataract

Perkins, E.S 325

Dynamics of Ascorbate in the Aqueous Humor and Tissues Surrounding Ocular Chambers

Kodama, T.; Kabasawa, I.; Tamura, O.; Reddy, V.N331

Increased Calcium Binding Capacity Associated with Genotypic Lens Opacities

Odeigah, P.G.C.; Patmore, L 338

Amino Acid Pattern in Human Aqueous Humor of Patients with Senile Cataract and Pri mary Open-Angle Glaucoma

Hannappel, E.; Pankow, G.; Grassl, F.; Brand, K.; Naumann, G.O.H

Interaction of Galactose and Dietary Protein Deficiency on Rat Lens

Ratnakar, K.S 344

Hypotensive Effects after Topical and Intra-Arterial Administration of $\alpha$-Adrenergic Ago nists in Isolated Perfused Rabbit Eyes

Pinxteren, P.C.M. van 349

Further Studies on the Effects of UV Radiation on the Human Lens

Lerman, S.; Megaw, J.M.; Moran, M.N 354

M-7 Lowers Rabbit Intraocular Pressure

Thörig, L.; Hoyng, P.F.J.; Timmermans, P.B.M.W.M.; Zwieten, P.A. van 362

Melatonergic Involvement in Diurnal Changes of Intraocular Pressure in Rabbit Eyes

Chiou, G.C.Y.; Aimoto, T.; Chiou, L.Y 373

Author Index Subject Index

379382 